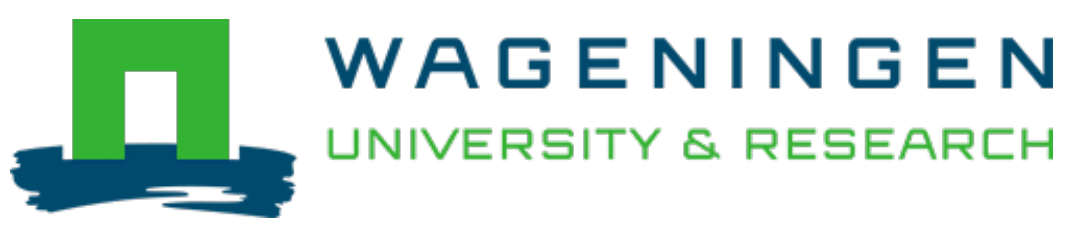

\title{
Distribution and ontogenetic habitat shifts of reefassociated shark species in the northeastern Caribbean
}

\author{
Marine Ecology Progress Series \\ Stoffers, T.; Graaf, M.; Winter, H.V.; Nagelkerke, L.A.J. \\ https://doi.org/10.3354/meps 13688
}

This article is made publicly available in the institutional repository of Wageningen University and Research, under the terms of article $25 \mathrm{fa}$ of the Dutch Copyright Act, also known as the Amendment Taverne. This has been done with explicit consent by the author.

Article 25 fa states that the author of a short scientific work funded either wholly or partially by Dutch public funds is entitled to make that work publicly available for no consideration following a reasonable period of time after the work was first published, provided that clear reference is made to the source of the first publication of the work.

This publication is distributed under The Association of Universities in the Netherlands (VSNU) 'Article $25 \mathrm{fa}$ implementation' project. In this project research outputs of researchers employed by Dutch Universities that comply with the legal requirements of Article $25 \mathrm{fa}$ of the Dutch Copyright Act are distributed online and free of cost or other barriers in institutional repositories. Research outputs are distributed six months after their first online publication in the original published version and with proper attribution to the source of the original publication.

You are permitted to download and use the publication for personal purposes. All rights remain with the author(s) and / or copyright owner(s) of this work. Any use of the publication or parts of it other than authorised under article $25 \mathrm{fa}$ of the Dutch Copyright act is prohibited. Wageningen University \& Research and the author(s) of this publication shall not be held responsible or liable for any damages resulting from your (re)use of this publication.

For questions regarding the public availability of this article please contact openscience.library@wur.nl 


\title{
Distribution and ontogenetic habitat shifts of reef-associated shark species in the northeastern Caribbean
}

\author{
Twan Stoffers ${ }^{1, *}$, Martin de Graaf ${ }^{2}$, Hendrik V. Winter ${ }^{1,2}$, Leopold A. J. Nagelkerke ${ }^{1}$ \\ ${ }^{1}$ Aquaculture and Fisheries Group, Wageningen University \& Research, PO Box 338, 6700 AH Wageningen, The Netherlands \\ ${ }^{2}$ Wageningen Marine Research, PO Box 68, 1970 AB IJmuiden, The Netherlands
}

\begin{abstract}
Understanding how reef-associated sharks utilise coastal reef habitats throughout their ontogeny is essential for their effective management. In this study, we assessed the distribution of sharks in the northern Caribbean Netherlands (Saba, Saba Bank and St Eustatius) and ontogenetic shifts in habitat and depth use of the 2 most observed species: Caribbean reef shark Carcharhinus perezi and nurse shark Ginglymostoma cirratum. We used stereo baited remote underwater video (stereo-BRUV) surveys at 376 sites. A total of 126 shark sightings (6 species) were recorded, with $C$. perezi $(\mathrm{n}=72)$ and $G$. cirratum $(\mathrm{n}=42)$ most frequently observed. The probability of recording at least 1 shark per deployment ranged from 0.19 to 0.37 and is comparable with shark occurrences in the small number of other stereo-BRUV studies in the Wider Caribbean Region. Habitat type was the most important factor driving reef-associated shark occurrences, with the highest probability of observing C. perezi and G. cirratum in soft-coral habitat. Additionally, occurrences of $C$. perezi were significantly influenced by the management zone, with highest probabilities of occurrence in no-fishing zones. Almost all observed reef-associated sharks $(95.6 \%)$ were juveniles, indicating that the study area may be a nursery area. Overall, both species were observed in deeper waters with increasing size, indicating ontogenetic shifts in depth use. Our findings imply that protected areas should not be limited to a single habitat or depth, but focus on protecting a large area with the range of habitats and depths necessary for reef-associated sharks to complete their life cycle.
\end{abstract}

KEY WORDS: Elasmobranchs · Conservation - Carcharhinus perezi - Ginglymostoma cirratum · Marine reserve $\cdot$ Baseline study $\cdot$ Caribbean Netherlands $\cdot$ BRUV $\cdot$ Baited remote underwater video

Resale or republication not permitted without written consent of the publisher

\section{INTRODUCTION}

As apex predators, sharks play an important functional role in the top-down control of oceanic and coastal ecosystems all around the world (Stevens et al. 2000, Ferretti et al. 2010). They are essential for the structure and functioning of many marine food webs (Baum \& Worm 2009, Osgood \& Baum 2015) and can also generate important non-consumptive economic value, e.g. dive tourism (Haas et al. 2017). Globally, one-quarter of all elasmobranch species face the risk of extinction (Dulvy et al. 2014), and al- most $20 \%$ of the reef-associated sharks in coastal reef ecosystems are considered functionally extinct (MacNeil et al. 2020). The global decline of sharks has been attributed to a combination of slow reproductive life-history characteristics (Cortés 2000), high levels of fishing pressure (Baum \& Myers 2004, Myers et al. 2007, García et al. 2008), and habitat degradation (Knip et al. 2010, Espinoza et al. 2014). As coastal reef ecosystems become increasingly affected by anthropogenic impacts and global warming (Bellwood et al. 2004, De'ath et al. 2012), understanding how reefassociated sharks utilise coastal reef habitats through- 
out their ontogeny is increasingly important for the effective management of these species and ecosystems, both globally and locally (Papastamatiou et al. 2009, Heupel et al. 2019). Ontogenetic shifts in habitat use occur in many shark species, caused by changes in species-specific diet, foraging behaviour and vulnerability to predation (Dahlgren \& Eggleston 2000, Knip et al. 2011, Werry et al. 2011).

The Caribbean region has traditionally been an area with small and localised fishing activities (Fitzpatrick \& Keegan 2007). However, regional nonsustainable fishing activities have steeply increased since the 1950s (Jackson 1997), resulting in a collapse of many coastal reef ecosystems (Hughes 1994, Jackson et al. 2001, Gardner et al. 2003, Dulvy et al. 2014) and the continued absence of reef-associated sharks (Ward-Paige et al. 2010, MacNeil et al. 2020). In response to these localised extinctions (Stallings 2009), several Caribbean countries have established shark sanctuaries and implemented fisheries legislation to protect reef-associated sharks (Morgan et al. 2009, Kyne et al. 2012, Van Beek et al. 2014). For the assessment of reef-associated sharks and their effective protection in coastal reef habitats, data on their population status are essential. Such data are not available for many Caribbean countries (Arocha et al. 2002, Baum et al. 2003), despite the global increase of research on reef-associated shark populations in recent decades. Therefore, baseline studies to assess local shark distribution and population structure for future reference and studying ontogenetic habitat shifts help us to understand shark population dynamics (Fokkema et al. 2020). This is important for the assessment of the ecological efficacy of the marine reserves and shark sanctuaries, and hence the local conservation of reef-associated sharks.

We carried out a baseline study in the Yarari shark sanctuary in the exclusive economic zone (EEZ) waters of the northern Caribbean Netherlands, established for Saba in 2015 and for St Eustatius in 2018. For these islands, limited information is available on shark species distribution and status, due to little historical fisheries data and local fisheries not targeting sharks (de Graaf et al. 2015, 2017). In our study, we investigated shark distribution and length structure in the northern Caribbean Netherlands, as well as ontogenetic shifts in depth and habitat use of the 2 commonly observed reef-associated shark species: Caribbean reef shark Carcharhinus perezi (Poey 1876) and nurse shark Ginglymostoma cirratum (Bonnaterre 1788). We used stereo baited remote underwater video (stereo-BRUV) surveys, which is a non-invasive alternative to fishing surveys (Cappo et al. 2004, Brooks et al. 2011), and a globally accepted technique for studying shark populations (Bond et al. 2012, White et al. 2013, Goetze et al. 2018, MacNeil et al. 2020). Stereo-BRUV surveys also allow for the estimation of shark length, enabling us to study ontogenetic shifts in habitat use of the most common reef-associated sharks in the waters of Saba and St Eustatius.

\section{MATERIALS AND METHODS}

\subsection{Study locations}

Saba Bank and the islands of Saba and St Eustatius are located in the northeastern Caribbean and are part of the inner arc of the Lesser Antilles (Fig. 1). Saba Bank National Park consists of a large (roughly $2200 \mathrm{~km}^{2}$ ), shallow $(<60 \mathrm{~m})$ submerged carbonate platform located approximately $5 \mathrm{~km}$ to the southwest of the island of Saba. From the coralcovered shallow ridge along the eastern and southeastern edges (13-18 m), the bank gradually slopes down towards the west, eventually dropping off to a depth of over $1000 \mathrm{~m}$. For the protection of its rich biodiversity (Hoetjes \& Carpenter 2010), Saba Bank was designated as a Specially Protected Area and Wildlife (SPAW) Protected Area and as an Ecologically or Biologically Significant Marine Area (EBSA) by the Convention on Biological Diversity (CBD, www.cbd.int) in 2012. The small island of Saba $\left(13 \mathrm{~km}^{2}\right)$ is surrounded by Saba Marine Park, which extends out from the high tide level to a depth of $60 \mathrm{~m}$. The total surface area of the marine park is $13 \mathrm{~km}^{2}$. It was established in 1987 and includes a marine reserve $\left(4.3 \mathrm{~km}^{2}\right)$, where no fishing or anchoring is allowed. St Eustatius $\left(21 \mathrm{~km}^{2}\right)$ is surrounded by Statia National Marine Park, established in 1996, which has a surface area of $27.5 \mathrm{~km}^{2}$ and extends to a depth of $30 \mathrm{~m}$ and includes a northern $\left(1.6 \mathrm{~km}^{2}\right)$ and southern $\left(3.6 \mathrm{~km}^{2}\right)$ marine reserve. Fishing or anchoring is not allowed in the marine reserves. A rich diversity of habitats can be found in the marine parks, ranging from pristine coral reefs and large seagrass beds in the shallow parts, to rocks and rubble covered with encrusting coral, sandy areas and pinnacles in the deeper parts. Recently, the waters of Saba (in 2015), Saba Bank (2015) and St Eustatius (2018) were declared Yarari Marine Mammal and Shark Sanctuary, in which elasmobranchs and marine mammals are protected under Dutch law. 


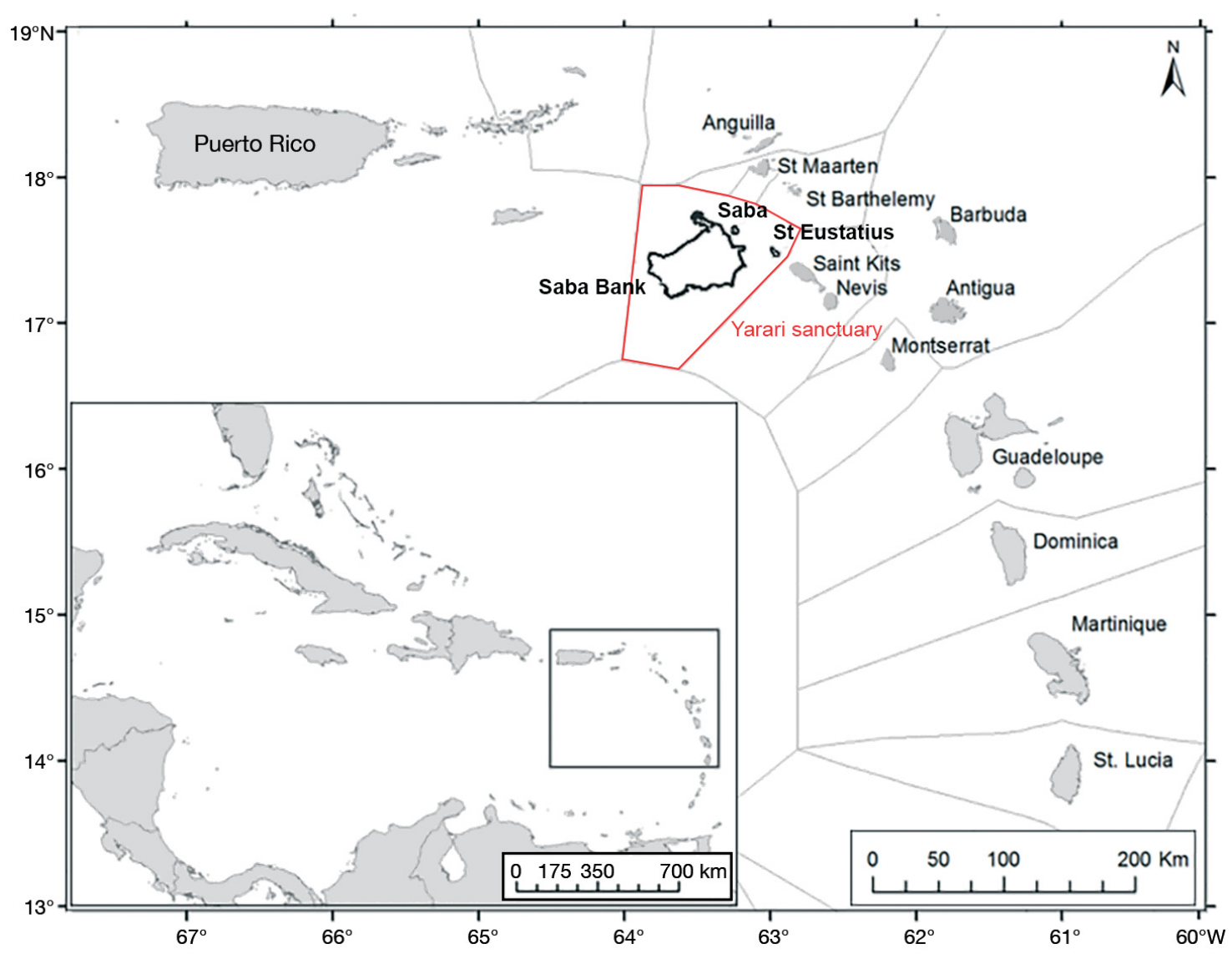

Fig. 1. Saba, Saba Bank, St Eustatius, and the Yarari shark sanctuary (inset: Wider Caribbean Region)

\subsection{Stereo-BRUV sampling}

We analysed underwater video recordings obtained with 3 stereo-BRUV units. Each unit consisted of 2 Canon Legria HFG10 digital cameras within waterproof housings mounted $0.7 \mathrm{~m}$ apart on a base bar. The cameras were inwardly converged at $8^{\circ}$ to gain an optimised field of view for length measurements. A synchronising diode and plastic-coated wire mesh bait bag were positioned in front of the cameras. Prior to field use, the stereo-BRUV units were calibrated using SeaGIS CAL V2.01 software (www.seagis.com.au). More detailed information on the stereo-BRUV system, the set-up and measurement and calibration process is given by Harvey \& Shortis (1995) and Watson et al. (2005).

All stereo-BRUV units were deployed during daylight hours between 09:00 and 17:00 h and were retrieved after a soaking time of 45-60 min. For each deployment, we used ca. $1 \mathrm{~kg}$ of pilchards Sardinops spp. as bait, and a minimum distance of $500 \mathrm{~m}$ was maintained between simultaneous deployments. We obtained 376 video recordings from 2012 to 2014. For
Saba, 108 stereo-BRUV deployments were conducted between July and December 2012. In the coastal waters of St Eustatius, we conducted 104 deployments between March and June 2013, and between March 2013 and February 2014 we conducted 164 deployments on Saba Bank.

In the coastal waters of Saba, we deployed stereoBRUV units at random, roughly every $500 \mathrm{~m}$ within a 15-100 m depth range, covering most of the marine park (where fishing is mostly allowed) including the marine reserve (which is assigned as a no-fishing area) (see Table 1). A similar strategy was used on St Eustatius, although the survey was limited to the $30 \mathrm{~m}$ depth boundary of Statia National Marine Park. Due to its large area, the whole of Saba Bank could not be covered. Instead, grids were used to subdivide Saba Bank into sampling areas of roughly $100 \mathrm{~km}^{2}$, and during a sampling day, up to 3 areas were visited (depending on what was practically feasible). At each of these locations, 3-6 deployments took place up to a maximum depth of $68 \mathrm{~m}$, always ensuring that the distance between them was at least $500 \mathrm{~m}$. Additionally, we deployed stereo-BRUV units at random 
along the shallow eastern ridge of the Saba Bank, where environmental heterogeneity was expected to be greatest (Toller et al. 2010).

\subsection{Video analysis}

We analysed the first $45 \mathrm{~min}$ of video recording after the stereo-BRUV unit settled on the sea bed. For each deployment, we identified sharks to species level, recorded the maximum number of individual sightings per species observed in a single frame (MaxN), and measured body length (total length, TL) in $\mathrm{cm}$. Each video recording was analysed at normal play speed by at least 2 trained and independent observers. Shark identifications were additionally checked by an expert to ensure accuracy in species identification. When images were ambiguous (6 of 132 shark sightings, $4.54 \%$ ), identification was limited to genus level and omitted from further analysis on species level, thus minimising the risk of misidentification. We did not identify or measure the length of sharks outside an $8 \mathrm{~m}$ range from the cameras, according to protocols established by Harvey \& Shortis (1995) and Watson et al. (2005). For sharks observed on only one of 2 stereo-BRUV cameras, no length estimate could be made.

We classified habitat types by dominance of (1) sand, (2) encrusting coral and/or rubble, (3) macro-algae, and (4) soft coral. Depth was categorised in classes $<25,25-60$, and $>60 \mathrm{~m}$, and fishing activity was categorised as present (marine park) or absent. Geographical locations were represented by our study areas as Saba, Saba Bank and St Eustatius. An overview of the environmental variables for each stereo-BRUV video deployment can be found in Table S1 in Supplement 1 at www.int-res.com/articles/ suppl/m665p145_supp1.pdf.

\subsection{Data analysis}

All analyses were performed in $\mathrm{R}$ version 3.6.2 ( $\mathrm{R}$ Core Team 2018). Data on reef-associated shark occurrences were first transformed into presenceabsence data, as only occasionally $(4.3 \%$ of the deployments) were 2 or 3 individual sharks recorded in a single video frame of the BRUV deployment. We used probability of occurrence to study habitat use patterns of Caribbean reef shark Carcharhinus perezi and nurse shark Ginglymostoma cirratum, defined as the proportion (between 0 and 1) of video recordings with a shark sighting, in a particular environmental setting. To identify important environmental drivers in explaining probability of occurrence patterns, logistic regression models (assuming a binomial data distribution and a logit-link function) were applied separately for each species. Explanatory variables were: (1) management zone (fishing, no fishing); (2) depth zone $(<25,25-60,>60 \mathrm{~m})$; and (3) habitat type (sand, encrusting coral and rubble, macro-algae, soft coral). In addition, (4) geographical location (Saba, Saba Bank, St Eustatius) was added as a fixed explanatory factor, as the local circumstances differed widely between the locations and it was expected that this could have had significant effects on the occurrence of sharks. Season was not included as an explanatory variable, as it was not expected to influence the distribution of sharks in this part of the Caribbean (Garla et al. 2006, Brooks et al. 2013). Also, the sampling strategy was not designed to analyse this factor.

We used the StepAIC function from the R package MASS (Ripley et al. 2013), which combines forward and backward model selection. Starting from an intercept-only model, the model was expanded with explanatory variables, and their 2- and 3-way interactions, until the model with the lowest Akaike information criterion (AIC) was found, which was considered the best fit. When differences in AIC were $<2$ between models, they were considered equivalent, and the simplest model was chosen. We calculated $95 \%$ confidence intervals with the 'predicts' function from the R package glm.predict (Schlegel 2019). Final models were checked for influential observations, by inspecting Cook's distance and standardised residuals, and for variance inflation with the vif function from the 'car' package (Fox \& Weisberg 2019).

Distribution of body length (TL) was analysed using the same model selection procedure as above, but with the assumption of a Gaussian data distribution and an identity link function. In addition, final models were tested for normality by inspecting Q-Q plots and applying Shapiro-Wilk's test. Homogeneity of residuals was tested with Levene's test.

\section{RESULTS}

\subsection{Shark species composition}

A total of 126 shark sightings of 6 species were recorded during 376 stereo-BRUV deployments (Tables $1 \&$ 2). Caribbean reef shark Carcharhinus perezi was most frequently observed (72 out of 126 shark sightings, $57 \%$ ), followed by nurse shark Ginglymostoma cirratum (42 out of 126 shark sightings, 
Table 1. Number of stereo baited remote underwater video recordings per sampling category: geographical location, depth zone, management zone and habitat type. Encr.: encrusting coral; (-) not sampled

\begin{tabular}{|c|c|c|c|c|c|c|}
\hline \multirow{2}{*}{ Habitat } & \multicolumn{2}{|c|}{$<25 \mathrm{~m}-$} & \multicolumn{2}{|c|}{$-25-60 \mathrm{~m}-$} & \multicolumn{2}{|c|}{$\longrightarrow 60 \mathrm{~m} \longrightarrow$} \\
\hline & Fishing & No fishing & Fishing & No fishing & Fishing & No fishing \\
\hline \multicolumn{7}{|l|}{ Saba $(n=108)$} \\
\hline Sand & 8 & 5 & 8 & 4 & 9 & - \\
\hline Encr./rubble & 8 & 2 & 10 & 2 & 15 & - \\
\hline Macro-algae & 3 & - & - & - & - & - \\
\hline Soft coral & 24 & 5 & 1 & 2 & 2 & - \\
\hline \multicolumn{7}{|c|}{ Saba Bank (n = 164) } \\
\hline Sand & 1 & - & 27 & - & - & - \\
\hline Encr./rubble & 6 & - & 24 & - & - & - \\
\hline Macro-algae & 42 & - & 6 & - & - & - \\
\hline Soft coral & 48 & - & 10 & - & - & - \\
\hline \multicolumn{7}{|c|}{ St Eustatius (n = 104) } \\
\hline Sand & 5 & 11 & - & - & - & - \\
\hline Encr./rubble & 19 & 3 & - & - & - & - \\
\hline Macro-algae & 6 & 3 & - & - & - & - \\
\hline Soft coral & 27 & 30 & - & - & - & - \\
\hline
\end{tabular}

$33 \%)$. Other observations were of blacktip shark Carcharhinus limbatus (Quoy \& Gaimard 1824), tiger shark Galeocerdo cuvier (Péron \& Lesueur 1822), great hammerhead shark Sphyrna mokarran (Rüppell 1837), and silky shark Carcharhinus falciformis (Müller \& Henle 1839). The probability of recording at least 1 shark per deployment varied between geographical locations from 0.19 (Saba) and 0.30 (Saba Bank) to 0.37 (St Eustatius). In 16 video deployments $(4.3 \%)$, a maximum of 3 sharks were observed. The largest recorded shark was a $G$. cuvier of $309 \mathrm{~cm}$ TL, whereas a $50 \mathrm{~cm} \mathrm{C.} \mathrm{pe-}$ rezi was the smallest.

The length-distribution of C. perezi did not differ between geo-

Table 2. Shark species composition recorded in stereo baited remote underwater video surveys between December 2012 and February 2014. MaxN: maximum number of individual sightings per species observed in a single frame; TL: total length; (-) no observations

\begin{tabular}{|c|c|c|c|c|c|c|c|c|}
\hline $\begin{array}{l}\text { Common name } \\
\text { (... shark) }\end{array}$ & Species & $\begin{array}{l}\text { Total no. } \\
\text { of recordings } \\
\text { (\% of total) }\end{array}$ & MaxN & $\begin{array}{c}\text { Saba } \\
(\mathrm{n}=108)\end{array}$ & $\begin{array}{l}\text { Saba Bank } \\
(\mathrm{n}=164)\end{array}$ & $\begin{array}{l}\text { St Eustatius } \\
\quad(\mathrm{n}=104)\end{array}$ & $\begin{array}{l}\text { Mean } \pm \text { SD } \\
(\mathrm{cm})\end{array}$ & $\begin{array}{c}\text { Range } \\
\text { (cm) }\end{array}$ \\
\hline Nurse & Ginglymostoma cirratum & $42(33)$ & 2 & 0.06 & 0.13 & 0.11 & $133 \pm 48$ & $55-218$ \\
\hline Blacktip & C. limbatus & $6(5)$ & 1 & 0.01 & 0.02 & 0.02 & $132 \pm 19$ & $82-178$ \\
\hline Tiger & Galeocerdo cuvier & $4(3)$ & 1 & - & 0.02 & - & $235 \pm 71$ & $139-309$ \\
\hline
\end{tabular}

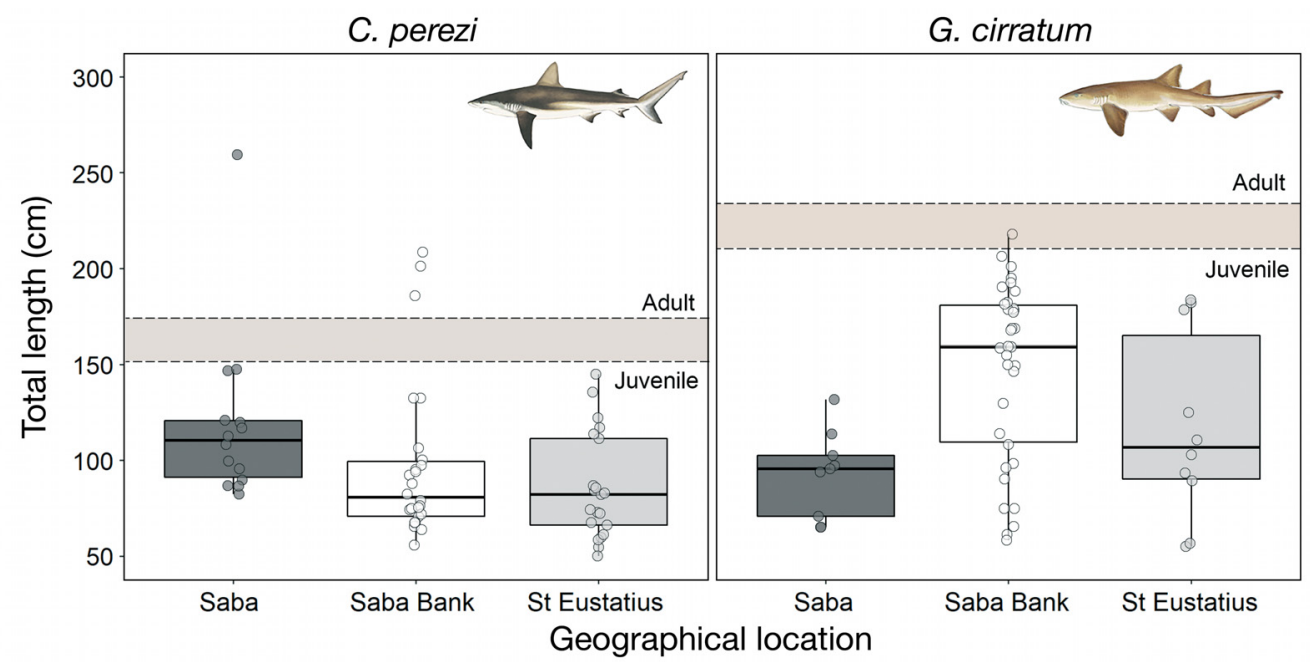

Fig. 2. Total length of Carcharhinus perezi and Ginglymostoma cirratum for Saba, Saba Bank and St Eustatius. Solid line: median; box: 25th and 75th percentiles; whiskers: 10th and 90th percentiles. Shaded areas with dashed lines indicate upper and lower bounds of (combined male and female) length at maturity for C. perezi (152-168 cm; Compagno 1984) and G. cirratum 

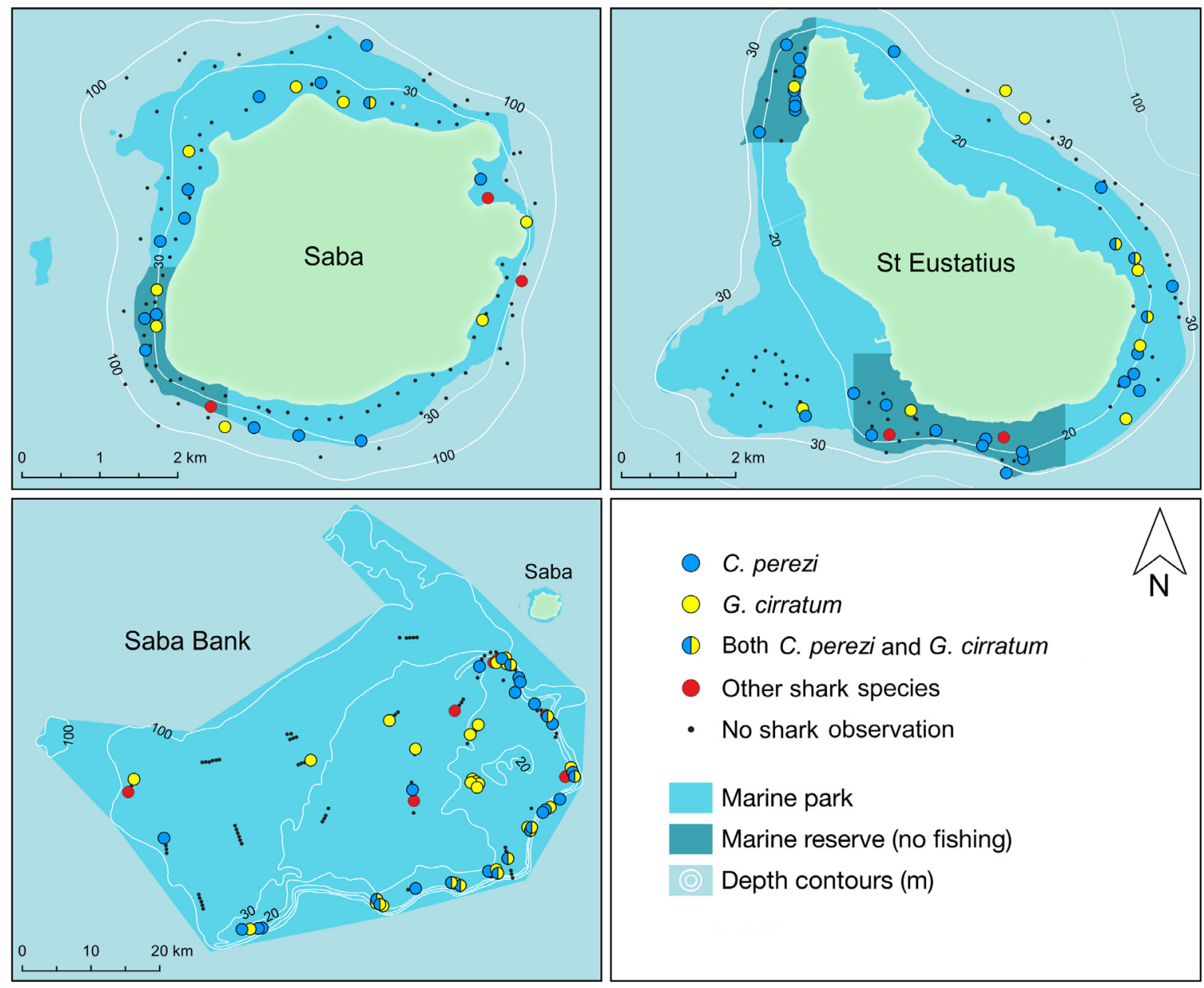

C. perezi

G. cirratum

(1) Both C. perezi and G. cirratum

- Other shark species

- No shark observation

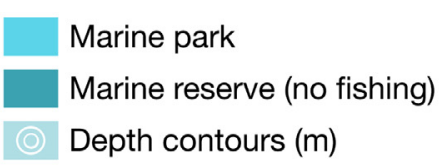

Fig. 3. Distribution of stereo baited remote underwater video deployments and sightings of Carcharhinus perezi, Ginglymostoma cirratum and other shark species in the waters surrounding Saba, St Eustatius, and the submerged carbonate platform of the Saba Bank

graphical locations (Fig. 2), while for G. cirratum, the largest specimens were recorded at Saba Bank, followed by St Eustatius. In the waters surrounding Saba, only small individuals of G. cirratum $(<140 \mathrm{~cm})$ were observed (Fig. 2). All of the observed G. cirratum (with the possible exception of one) and 57 of the 61 measured C. perezi were juveniles, based on their length (Compagno 1984, Bonfil 1997, Castro 2000, Tavares 2009).

Shark sightings were unevenly distributed for Saba Bank and St Eustatius (Fig. 3). On Saba Bank, sharks were most frequently recorded along the shallow eastern and southeastern edges of the bank (45 out of 62 shark sightings, $73 \%$ ), whereas in the deeper (>50 m) western and northern parts, only 4 $(6 \%)$ of the shark sightings on the bank were recorded. For Saba and St Eustatius, sharks were more evenly distributed around the island, except for most of the west coast of St Eustatius, where only 2 out of 43 shark sightings (5\%) were recorded. $C$. perezi and G. cirratum were observed at each geographical location, whereas G. cuvier was exclusively recorded on Saba Bank, and S. mokarran and $C$. falciformis only in Saban waters. Only for C. perezi and $G$. cirratum, for which sufficient numbers of sightings were available, was a detailed analysis on probability of occurrence and length performed.

\subsection{Probability of occurrence}

The final logistic regression model of the probability of occurrence of C. perezi showed statistically significant influences of habitat type and management zone, with the highest probabilities found in soft-coral habitats and in no-fishing zones (Table 3, Fig. 4). In addition, there was a significant interaction between the 2 factors, with the effect of fish- 
Table 3. Best-fitting (based on lowest Akaike information criterion) logistic regression models of probability of occurrence of Carcharhinus perezi and Ginglymostoma cirratum. Encr.: encrusting coral; bold: significant $(\mathrm{p}<0.05)$

\begin{tabular}{|c|c|c|c|c|c|}
\hline Species & Parameter & $\mathrm{p}$ & Estimate & SE & $z$ \\
\hline \multirow[t]{8}{*}{ C. perezi } & Intercept $($ Habitat type $=$ Sand + Management zone $=$ Fishing $)$ & $<0.0001$ & -4.04 & 1.01 & -4.01 \\
\hline & Habitat type = Encr./Rubble & 0.123 & 1.67 & 1.08 & 1.54 \\
\hline & Habitat type = Macro-algae & 0.083 & 1.90 & 1.10 & 1.74 \\
\hline & Habitat type $=$ Soft coral & 0.003 & 3.08 & 1.03 & 2.99 \\
\hline & Management zone $=$ No fishing & 0.002 & 3.42 & 1.11 & 3.08 \\
\hline & Habitat type $=$ Encr.$/$ Rubble $\times$ Management zone $=$ No fishing & 0.075 & -2.84 & 1.60 & -1.78 \\
\hline & Habitat type $=$ Macro-algae $\times$ Management zone $=$ No fishing & 0.730 & -0.59 & 1.71 & -0.35 \\
\hline & Habitat type $=$ Soft coral $\times$ Management zone $=$ No fishing & 0.005 & -3.32 & 1.19 & -2.80 \\
\hline \multirow[t]{4}{*}{ G. cirratum } & Intercept (Habitat type = Sand) & $<0.0001$ & -4.34 & 1.01 & -4.32 \\
\hline & Habitat type = Encr./Rubble & 0.042 & 2.16 & 1.07 & 2.03 \\
\hline & Habitat type = Macro-algae & 0.022 & 2.47 & 1.08 & 2.30 \\
\hline & Habitat type $=$ Soft coral & 0.012 & 2.59 & 1.03 & 2.51 \\
\hline
\end{tabular}

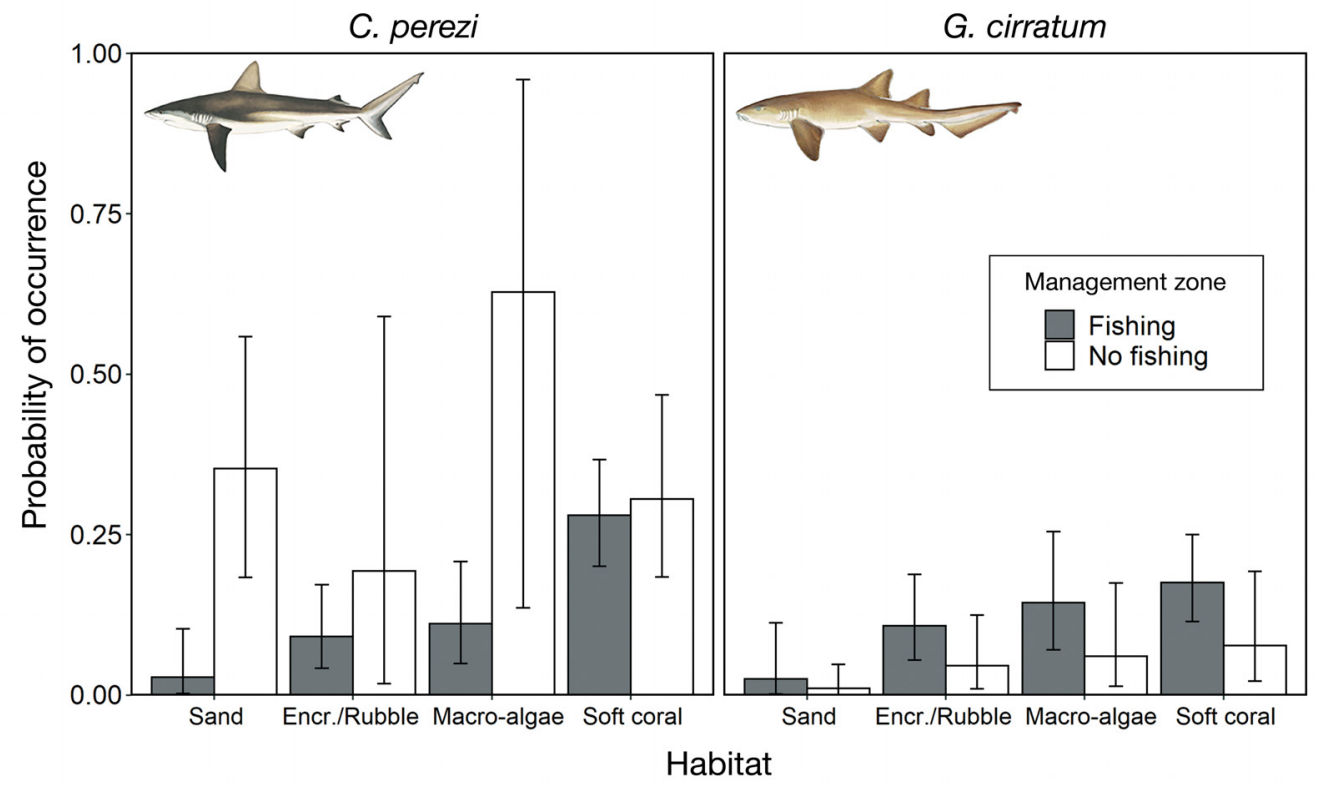

Fig. 4. Probability of occurrence for Carcharhinus perezi and Ginglymostoma cirratum by management zone and habitat type. Encr.: encrusting coral. Error bars: $95 \%$ confidence intervals

ing being smallest in the soft-coral habitat. There was no significant effect of either depth zone or geographical location.

For G. cirratum, only habitat type significantly influenced probability of occurrence (Table 3, Fig. 4), with the lowest probabilities recorded over sand. In contrast to C. perezi, no influence of fishing was found. Similarly, no effect of depth zone, or geographical location was observed. An overview of the stepwise procedures in our analysis, including fitted models and AIC values for both species, can be found in Tables S2-S5 in Supplement 2 at www.int-res. com/articles/suppl/m665p145_supp2.pdf

\subsection{Body length}

TL of $C$. perezi was significantly influenced by depth zone only (Table 4, Fig. 5). The mean length was almost $50 \mathrm{~cm}$ larger in waters between 25 and $60 \mathrm{~m}$ deep, than in shallow waters of $<25 \mathrm{~m}$. We did not detect any statistically significant effect of habitat type, management zone, or geographical location on body length for this species. For $G$. cirratum, the mean length was also significantly larger in waters between 25 and $60 \mathrm{~m}$ deep, as compared to shallower waters (on average, $>60 \mathrm{~cm}$ larger). In addition, in contrast to $C$. perezi, significantly larger individuals 
Table 4. Best-fitting (based on lowest Akaike information criterion) Gaussian regression models of body length (measured in total length) of Carcharhinus perezi and Ginglymostoma cirratum. Encr.: encrusting coral; bold: significant (p < 0.05)

\begin{tabular}{|c|c|c|c|c|c|}
\hline Species & Parameter & $\mathrm{p}$ & Estimate & $\mathrm{SE}$ & $z$ \\
\hline \multirow[t]{2}{*}{ C. perezi } & Intercept (Depth zone $=<25 \mathrm{~m}$ ) & $<0.0005$ & 89.7 & 5.0 & 17.90 \\
\hline & Depth zone $=25-60 \mathrm{~m}$ & $<0.0005$ & 48.8 & 11.8 & 4.14 \\
\hline \multirow[t]{5}{*}{ G. cirratum } & Intercept $($ Depth zone $=<25 \mathrm{~m}+$ Habitat type $=$ Sand $)$ & 0.002 & 91.26 & 28.00 & 3.26 \\
\hline & Depth zone $=25-60 \mathrm{~m}$ & $<0.0001$ & 62.37 & 14.95 & 4.17 \\
\hline & Habitat type = Encr./Rubble & 0.626 & 14.41 & 29.44 & 0.49 \\
\hline & Habitat type = Macro-algae & 0.021 & 69.93 & 29.33 & 2.38 \\
\hline & Habitat type $=$ Soft coral & 0.459 & 21.42 & 28.66 & 0.75 \\
\hline
\end{tabular}

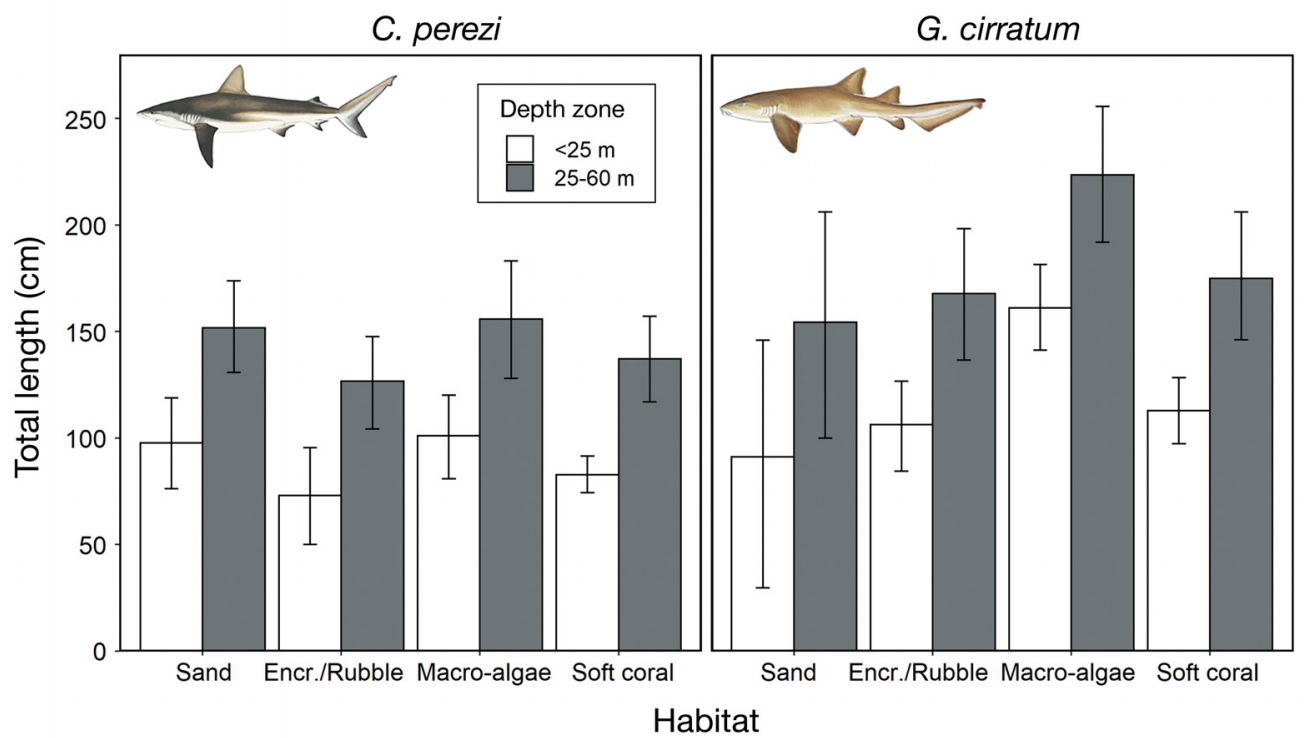

Fig. 5. Mean total length for Carcharhinus perezi (left) and Ginglymostoma cirratum (right) by depth zone and habitat type. Encr.: encrusting coral. Error bars: 95\% confidence intervals

of G. cirratum were found in macro-algal habitats, as compared to other habitat types (Table 4, Fig. 5). No statistically significant effect of management zone, or geographical location on body length of G. cirratum was detected.

\section{DISCUSSION}

This study is the first comprehensive assessment of shark occurrence and distribution in the northern Caribbean Netherlands using stereo-BRUV. In total, 6 shark species were observed, and ontogenetic shifts in habitat and depth use were indicated for the 2 most commonly observed reef-associated species. We found that, independent of habitat or management zone, significantly larger individuals of both Caribbean reef shark Carcharhinus perezi and nurse shark Ginglymostoma cirratum were observed in deeper waters (Fig. 5, Table 4), indicating ontogenetic shifts in depth use. For G. cirratum, an ontogenetic shift in physical habitat use was also observed, since significantly larger individuals were found in a macroalgal habitat. Habitat was important in explaining reef-associated shark occurrences too, with the highest probability of observing C. perezi and G. cirratum in soft-coral habitats (Fig. 4, Table 3). Additionally, occurrences of $C$. perezi were significantly influenced by the management zone, with the highest probabilities of occurrence in no-fishing zones, highlighting the importance of marine protected areas.

A limitation of our study is the unbalanced sampling design (Table 1), caused by the differences between the geographical locations and by limited sampling time. This resulted in different locations being sampled at different times of the year, which meant that proper analysis of the effects of seasonality on the occurrence of different shark species was not possible. 
Previous studies have shown either an absence of seasonal movements by C. perezi (e.g. in Brazil: Garla et al. 2006), or clear seasonality (e.g. in the Bahamas: Brooks et al. 2013, Shipley et al. 2017). These latter authors explain the discrepancy between geographic locations in terms of water temperature seasonality, which is strongest in northerly latitudes. As our study area does not show strong temperature dynamics (https://seatemperature.info), it is not expected that seasonal movement patterns will play a significant role in the occurrence of $C$. perezi. The limited information on movement behaviour of G. cirratum (e.g. Garla et al. 2017) does not indicate clear seasonality either. Given the probably limited role of seasonal movement patterns, our results on the effects of habitat type, depth zone, and management zone appear robust, especially since they are consistent in 3 diverse geographical locations.

\subsection{Stereo-BRUV limitations}

Stereo-BRUV surveys may result in an underestimation of elasmobranch abundance and species richness, especially when MaxN is used in the video analysis process (Schobernd et al. 2014). MaxN is a conservative method for estimating abundances, since it eliminates the effect of double counting and does not distinguish between individuals of the same species occurring in the same video deployment. Its use may lead to an underestimation of elasmobranch abundance with a factor ranging from 1.1 to 2.4, for common to more rare species respectively (Sherman et al. 2018). Furthermore, suboptimal soaking time of the deployments can also lead to shark population underestimation (Currey-Randall et al. 2020). Optimal soaking time for MaxN and species richness analysis with (stereo-)BRUV is between 63 and $77 \mathrm{~min}$ and, especially for rare species and in areas with generally low abundance, suboptimal soaking times may result in underestimation of shark abundance and species richness (Currey-Randall et al. 2020).

Since we used a more conservative approach than MaxN (presence-absence) for the analysis of shark abundances, and we manually cut off video recordings after 45 min soaking time to ensure consistency in the data (St Eustatius recordings were limited to $45 \mathrm{~min}$ soaking time), we anticipate to have underestimated shark abundance and species richness in our study. However, we expect the outcomes of our models regarding habitat associations of C. perezi and G. cirratum to be robust, since underestimation mainly becomes an issue when studying rare species (Sher- man et al. 2018, Currey-Randall et al. 2020), and these 2 species were abundant throughout the study area. Furthermore, we expect that we found similar habitat associations as we would have if MaxN was used, since in only $4.3 \%$ of the deployments were 2 or 3 sharks, instead of 1 individual shark, observed in a single frame. For these reasons we decided to use the simplest modelling approach and use presence-absence data. Despite the limitations of our study, we believe that stereo-BRUV was suitable for studying habitat associations of reef-associated sharks, and for providing a baseline assessment of shark diversity, occurrence, distribution and length structure in the waters of Saba, Saba Bank and St Eustatius, due to its capacity to estimate shark body length, its non-invasive nature, and its ability to sample a variety of habitats and depths.

\subsection{Reef-associated shark occurrence and distribution}

In the Wider Caribbean Region, G. cirratum is the most commonly observed shark species, in longline (Pikitch et al. 2005, Brooks et al. 2011), SCUBA (Ward-Paige et al. 2010) and stereo-BRUV surveys (Brooks et al. 2011, Bond et al. 2012, Bruns \& Henderson 2020). Carcharhinid sharks, such as $C$. perezi, are less frequently observed in the Caribbean, although this species can be very abundant locally (Dwyer et al. 2020). In Caribbean countries with high human population densities, such as Jamaica, Dominican Republic, Cuba and Puerto Rico, carcharhinid sharks are largely absent (WardPaige et al. 2010, MacNeil et al. 2020). In our study, both C. perezi and G. cirratum were frequently observed, with relative abundances (sharks per $45 \mathrm{~min}$ of stereo-BRUV deployment) varying between 0.14 and 0.27 and between 0.08 and 0.14 respectively (Table 5). These abundances were comparable to BRUV studies in other Caribbean regions with low human population densities, such as Turks and Caicos (Bruns \& Henderson 2020) and the Cayman Islands (Ormond et al. 2016), and regions with strict fishing regulations and conservation measures in place, such as the Bahamas (Brooks et al. 2011) and Belize (Bond et al. 2012). These studies expressed relative abundances of sharks per hour and are therefore less conservative than our study. According to the global study by Currey-Randall et al. (2020), we expect that we recorded over $75 \%$ of the total reef-associated shark occurrences with $45 \mathrm{~min}$ stereo-BRUV deployments, compared to approximately $90 \%$ of the shark occurrences if we would 
Table 5. Overview of relative abundances (sharks per hour) of Carcharhinus perezi and Ginglymostoma cirratum obtained by stereo baited remote underwater video surveys in the Caribbean region. (-) not studied

\begin{tabular}{|lcccl|}
\hline \multirow{2}{*}{ Study area } & \multicolumn{3}{c}{ Sharks per hour } & \multicolumn{1}{c|}{ Reference } \\
\cline { 2 - 4 } & C. perezi & G. cirratum & Combined & \\
\hline Saba & $0.14^{\mathrm{a}}$ & $0.08^{\mathrm{a}}$ & $0.22^{\mathrm{a}}$ & Present study \\
Saba Bank & $0.20^{\mathrm{a}}$ & $0.14^{\mathrm{a}}$ & $0.34^{\mathrm{a}}$ & Present study \\
St Eustatius & $0.27^{\mathrm{a}}$ & $0.11^{\mathrm{a}}$ & $0.38^{\mathrm{a}}$ & Present study \\
Belize & 0.24 & - & 0.25 & Bond et al. (2012) \\
The Bahamas & 0.08 & 0.21 & 0.34 & Brooks et al. (2011) \\
Cayman Islands & 0.15 & - & - & Ormond et al. (2016) \\
Turks and Caicos & 0.27 & 0.32 & 0.59 & Bruns \& Henderson (2020) \\
Wider Caribbean & - & $0.07^{\mathrm{b}}$ & $0.10^{\mathrm{b}}$ & Ward-Paige et al. (2010) \\
Region & \multicolumn{5}{c}{} & & \\
aSharks per 45 min deployment & & \\
abotained via diver surveys & & & \\
\hline
\end{tabular}

et al. 2014). For G. cirratum, it was estimated that 0.013 individuals were caught per trap lift in the lobster trap fishery in 2015 , with an estimated 2000 individuals caught and released alive (de Graaf et al. 2017). For C. perezi, an estimated 45 individuals were landed per year (2011-2016) on Saba and St Eustatius combined (de Graaf et al. 2017). Historical observations by Toller \& Lundvall (2008) and Dilrosun (2000) report similar (low) catch and landing rates for sharks on Saba and St Eustatius. have used stereo-BRUV recordings with optimised soaking times. Highest relative abundances of reefassociated sharks in the Wider Caribbean Region were reported for remote islands, such as Cayo Serranilla and Old Province Island (Colombia), with relative abundances twice as high (0.24-0.57 sharks $\left.\mathrm{h}^{-1}\right)$ for G. cirratum and C. perezi $(0.36-1.05$ sharks $\mathrm{h}^{-1}$ ) (Dwyer et al. 2020). Unlike most of the aforementioned stereo-BRUV studies, our study also included the sampling of deep-water habitats $(>50 \mathrm{~m}$ depth) and large sand flats, which is generally not the preferred habitat for $C$. perezi (Pikitch et al. 2005, Chapman et al. 2007, Shipley et al. 2017, Casselberry et al. 2020) and G. cirratum (Garla et al. 2017), leading to overall lower relative abundances in our study, compared to other studies. For these reasons, we postulate that C. perezi and G. cirratum populations on Saba, Saba Bank and St Eustatius appear to be relatively healthy, when compared to their current status in the Wider Caribbean Region (but see Dwyer et al. 2020), although historical references on population abundance of these sharks are not available (Ward-Paige et al. 2010).

The relatively high reef-associated shark presence in our study area may be explained by the lack of destructive industrial-scale fishery practices (directed shark fisheries, shark finning, longlining and gillnetting) and low human population densities (MacNeil et al. 2020). In 2019, roughly 5100 people inhabited the islands of Saba and St Eustatius combined, so they are among the least densely populated islands of the Caribbean region. The only commercial fisheries on these islands are the deepwater snapper trap fishery and a small-scale lobster trap fishery, which do not target sharks (Van Beek

\subsection{Life stage and habitat use}

We used the upper ends of the maturation length ranges to estimate that in our study, only $6 \%$ of the recorded C. perezi (4 out of 72) and 1 individual of G. cirratum were sexually mature (Compagno 1984, Bonfil 1997, Castro 2000, Tavares 2009) (our Fig. 2). For other Caribbean regions, higher percentages of mature C. perezi were reported. For example, in Belize, using both stereo-BRUV (Bond et al. 2012) and longline surveys (Bond et al. 2017), ca. $25 \%$ of the encountered $C$. perezi were of adult length, whereas in the Bahamas, Brooks et al. (2013) found that over $35 \%$ of $C$. perezi caught with longlines were sexually mature. No length data on G. cirratum for the Caribbean were available for comparison. Off the east coast of Brazil, Ferreira et al. (2013) and Garla et al. (2017) found the proportion of mature G. cirratum caught with longlines to range between 6 and $36 \%$. Since mature reef-associated sharks were not frequently observed, we were not able to identify specific habitats for this life stage, and with current fishing pressure (de Graaf et al. 2017), it is highly unlikely that adult sharks are overfished in our study area. We suggest that the high numbers of juvenile shark sightings in our study imply that the reefs surrounding Saba and St Eustatius and Saba Bank are mainly used as a nursery area by reef-associated sharks from a wider area. Therefore, we propose that future research focusses on the identification, the distribution of and linkages between local nursery areas, as well as how habitats within these nursery areas are used by reef-associated sharks during different life stages. This concept was introduced by Nagelkerken et al. (2015) as 'seascape nurseries', in 
which nurseries are conceptualised as a spatially explicit seascape consisting of multiple mosaics of habitat patches that are functionally connected.

We found no significant effect of geographical location on the probability of occurrence of reefassociated sharks, indicating that the observed habitat associations of $C$. perezi and G. cirratum were not location-specific. Habitat type was the most important factor driving reef-associated shark occurrences, with the highest probability of observing C. perezi and G. cirratum in soft-coral habitat (Fig. 4, Table 3). Generally, habitats with lower structural complexity (sand and encrusting coral/rubble) resulted in a lower probability of occurrences for both species. These shark-habitat associations were reflected in the distribution patterns of $C$. perezi and G. cirratum on Saba Bank. Especially for C. perezi, occurrences were highest along the eastern and southeastern reef shelf (Fig. 3), which was characterised by a small and shallow ridge of highly complex reef (Toller et al. 2010). Within the Caribbean region, similar habitat associations for C. perezi were reported (Bond et al. 2017, Bruns \& Henderson 2020, Casselberry et al. 2020). High levels of site fidelity are commonly observed in C. perezi (Garla et al. 2006, Bond et al. 2012, Shipley et al. 2018, Casselberry et al. 2020, Dwyer et al. 2020), which is primarily associated with shallow coral-reef habitats and reef edges near dropoffs (Pikitch et al. 2005, Brooks et al. 2013, Bond et al. 2017, Bruns \& Henderson 2020). From these reef edges, frequent deep dives over $50 \mathrm{~m}$ were made, especially by larger individuals (Shipley et al. 2018, Casselberry et al. 2020). G. cirratum is a more wideranging shark species (Garla et al. 2017, Dwyer et al. 2020), probably due to wider habitat preference throughout its development, varying from sand flats, seagrass beds and (coral) reef habitats (Castro 2000, Pratt et al. 2018, Bruns \& Henderson 2020, Casselberry et al. 2020).

Drivers for ontogenetic habitat shifts generally result from changing trade-offs between different forage needs and opportunities, competition for food, and predator avoidance or perceived predation risk, in relation to increasing body size (Dahlgren \& Eggleston 2000, Snover 2008). Independent of habitat type, significantly larger individuals of both $C$. perezi and G. cirratum were observed in deeper waters (Fig. 5, Table 4), indicating ontogenetic shifts in depth use, also for juveniles. Adult C. perezi are known to frequently use deeper water habitats on the reef (Pikitch et al. 2005, Chapman et al. 2007) and along the reef shelf (Shipley et al. 2018, Casselberry et al. 2020). Since C. perezi probably does not act as the sole apex predator in many Caribbean coral reef ecosystems (Bond et al. 2018), such ontogenetic changes in habitat use allow for avoidance of competition for food with large-bodied teleosts (Heithaus et al. 2008, Casselberry et al. 2020) and for exploitation of a diverse array of prey items (Bond et al. 2018, Shipley et al. 2018). Similar ontogenetic habitat shifts were reported for G. cirratum in Florida (Castro 2000), where smaller individuals were frequently found in shallow reefs, under rocks or ledges, whereas larger juveniles and adults were found in deeper reef habitats and rocky areas at depths up to $75 \mathrm{~m}$. However, ontogenetic habitat shifts in G. cirratum are poorly studied, with some evidence to support that individuals occupy deeper parts of the reef with increasing age (Castro 2000, Casselberry et al. 2020). Similar to C. perezi, the ontogenetic habitat shift in G. cirratum may also be related to a shift in prey type consumption. Significantly more sharks, and of larger size, were found in (deeper) macroalgal habitats on Saba Bank (Tables 3 \& 4), where large numbers of Caribbean spiny lobster Panulirus argus (Latreille 1804) and other invertebrates can be found (Smith \& Herrkind 1992, de Graaf et al. 2017). Panulirus argus is known to be an important food source for G. cirratum (Cruz et al. 1986, Castro 2000), which is supported by the frequent capture of $G$. cirratum in lobster traps on Saba Bank (de Graaf et al. 2017). Especially larger, more mobile sharks may travel large distances and inhabit areas with high densities of this food source (Cruz et al. 1986). These larger individuals are also less vulnerable to predation by other large sharks, such as Galeocerdo cuvier, which is known to prey on small G. cirratum (Lowe et al. 1996, Castro 2000, Heithaus 2001, Simpfendorfer et al. 2001), leading to ontogenetic shifts in the habitat use of their prey species (Heithaus et al. 2002).

\subsection{Implications for management}

In recent years, it has become apparent that marine reserves can be effective in the conservation of reefassociated shark species (Heupel et al. 2009, McCook et al. 2010, Speed et al. 2018, MacNeil et al. 2020). However, not all shark species benefit equally from these local safe havens (Dwyer et al. 2020). This is also apparent from our study, as we observed a positive effect of the rather small marine reserves on Saba and St Eustatius $\left(9.5 \mathrm{~km}^{2}\right.$ in total) on C. perezi occurrences, with significantly more sharks observed in the reserve (Table 3). However, no such effect was observed for G. cirratum, probably due to a wider 
habitat preference compared to C. perezi (Garla et al. 2017, Dwyer et al. 2020). This implies that C. perezi benefits more from local (small-scale) protection than G. cirratum in Saba and St Eustatius, and that larger marine reserves are required to effectively protect both species (Dwyer et al. 2020, MacNeil et al. 2020). Furthermore, protected areas should not be limited to a single habitat or depth, but focus on protecting a large area with the range of habitats and depths necessary for reef-associated sharks to complete their life history.

Our study also implies that regional migrations of adult sharks for mating and pupping might be important for sustaining the health of local shark populations in the waters of Saba, St Eustatius and Saba Bank. For the effective protection of sharks on a regional scale, further studies are needed, in terms of both wider-scale dispersal and individual shark movement patterns between the waters of the Caribbean Netherlands and neighbouring areas.

Acknowledgements. This research was funded by the Ministry of Economic Affairs of the Netherlands. We are grateful to the employees of the Saba Conservation Foundation (SCF), Saba Bank Management Unit (SBMU) and St Eustatius National Parks (STENAPA) for assistance in fieldwork activities. Special thanks to Jimmy van Rijn, Wouter van Looijengoed, Tiedo van Kuijk, and Jelmer Pander for help in data collection. We also thank Matthew Needle for help with the illustrations, Marcel Machiels and Jan Jaap Poos for input in the data analysis, and Miranda Maybank for proofreading the manuscript. We thank the Food and Agriculture Organization of the United Nations (FAO) for permission to use their scientific shark illustrations.

\section{LITERATURE CITED}

Arocha F, Arocha O, Marcano LA (2002) Observed shark bycatch from the Venezuelan tuna and swordfish fishery from 1994 through 2000. ICCAT Collect Vol Sci Pap 54: 1123-1131

Baum JK, Myers RA (2004) Shifting baselines and the decline of pelagic sharks in the Gulf of Mexico. Ecol Lett 7:135-145

Baum JK, Worm B (2009) Cascading top-down effects of changing oceanic predator abundances. J Anim Ecol 78: 699-714

Baum JK, Myers RA, Kehler DG, Worm B, Harley SJ, Doherty PA (2003) Collapse and conservation of shark populations in the Northwest Atlantic. Science 299:389-392

Bellwood DR, Hughes TP, Folke C, Nyström M (2004) Confronting the coral reef crisis. Nature 429:827-833

Bond ME, Babcock EA, Pikitch EK, Abercrombie DL, Lamb NF, Chapman DD (2012) Reef sharks exhibit site-fidelity and higher relative abundance in marine reserves on the Mesoamerican Barrier Reef. PLOS ONE 7:e32983

Bond ME, Valentin-Albanese J, Babcock EA, Abercrombie D and others (2017) Abundance and size structure of a reef shark population within a marine reserve has remained stable for more than a decade. Mar Ecol Prog Ser 576: $1-10$

*Bond ME, Valentin-Albanese J, Babcock EA, Hussey NE, Heithaus MR, Chapman DD (2018) The trophic ecology of Caribbean reef sharks (Carcharhinus perezi) relative to other large teleost predators on an isolated coral atoll. Mar Biol 165:67

Bonfil R (1997) Status of shark resources in the Southern Gulf of Mexico and Caribbean: implications for management. Fish Res 29:101-117

* Brooks EJ, Sloman KA, Sims DW, Danylchuk AJ (2011) Validating the use of baited remote underwater video surveys for assessing the diversity, distribution and abundance of sharks in the Bahamas. Endang Species Res 13: 231-243

Brooks EJ, Sims DW, Danylchuk AJ, Sloman KA (2013) Seasonal abundance, philopatry and demographic structure of Caribbean reef shark (Carcharhinus perezi) assemblages in the north-east Exuma Sound, The Bahamas. Mar Biol 160:2535-2546

* Bruns S, Henderson AC (2020) A baited remote underwater video system (BRUVS) assessment of elasmobranch diversity and abundance on the eastern Caicos Bank (Turks and Caicos Islands); an environment in transition. Environ Biol Fishes 103:1001-1012

Cappo M, Speare P, De'ath G (2004) Comparison of baited remote underwater video stations (BRUVS) and prawn (shrimp) trawls for assessments of fish biodiversity in inter-reefal areas of the Great Barrier Reef Marine Park. J Exp Mar Biol Ecol 302:123-152

Casselberry GA, Danylchuk AJ, Finn JT, DeAngelis BM and others (2020) Network analysis reveals multispecies spatial associations in the shark community of a Caribbean marine protected area. Mar Ecol Prog Ser 633:105-126

Castro JI (2000) The biology of the nurse shark, Ginglymostoma cirratum, off the Florida east coast and the Bahama Islands. Environ Biol Fishes 58:1-22

* Chapman DD, Pikitch EK, Babcock EA, Shivji MS (2007) Deep-diving and diel changes in vertical habitat use by Caribbean reef sharks Carcharhinus perezi. Mar Ecol Prog Ser 344:271-275

Compagno LJ (1984) FAO Species catalogue, Vol 4. Sharks of the world. An annotated and illustrated catalogue of shark species known to date. Part 2: Carcharhiniformes. FAO Fish Synopsis 125. FAO, Rome

* Cortés E (2000) Life history patterns and correlations in sharks. Rev Fish Sci 8:299-344

Cruz R, Brito R, Díaz E, Lalana R (1986) Ecología de la langosta (Panulirus argus) al SE de la Isla de la Juventud. I. Colonización de arrecifes artificiales. Rev Invest Mar 7: 3-17

Currey-Randall LM, Cappo M, Simpfendorfer CA, Farabaugh NF, Heupel MR (2020) Optimal soak times for Baited Remote Underwater Video Station surveys of reef-associated elasmobranchs. PLOS ONE 15:e0231688

Wahlgren CP, Eggleston DB (2000) Ecological processes underlying ontogenetic habitat shifts in a coral reef fish. Ecology 81:2227-2240

De'ath G, Fabricius KE, Sweatman H, Puotinen M (2012) The 27-year decline of coral cover on the Great Barrier Reef and its causes. Proc Natl Acad Sci USA 109:17995-17999

* de Graaf M, Piontek S, Miller D, Brunel T, Nagelkerke L (2015) Status and trends of St. Eustatius coral reef ecosystem and fisheries: 2015 report card (No. C167/15). IMARES Wageningen. http://edepot.wur.nl/367856 
de Graaf M, Brunel T, Nagelkerke L, Debrot A (2017) Status and trends Saba Bank fisheries: 2015 (Ser. Wageningen Marine Research report, c077/17). Wageningen Marine Research. https://doi.org/10.18174/424549

Dilrosun F (2000) Monitoring the Saba Bank fishery. Department of Public Health and Environmental Hygiene, Environmental Division, Willemstad

Dulvy NK, Fowler SL, Musick JA, Cavanagh RD and others (2014) Extinction risk and conservation of the world's sharks and rays. eLife 3:e00590

Dwyer RG, Krueck NC, Udyawer V, Heupel MR and others (2020) Individual and population benefits of marine reserves for reef sharks. Curr Biol 30:480-489.e5

* Espinoza M, Cappo M, Heupel MR, Tobin AJ, Simpfendorfer CA (2014) Quantifying shark distribution patterns and species-habitat associations: implications of marine park zoning. PLOS ONE 9:e106885

Ferreira LC, Afonso AS, Castilho PC, Hazin FH (2013) Habitat use of the nurse shark, Ginglymostoma cirratum, off Recife, Northeast Brazil: a combined survey with longline and acoustic telemetry. Environ Biol Fishes 96:735-745

Ferretti F, Worm B, Britten GL, Heithaus MR, Lotze HK (2010) Patterns and ecosystem consequences of shark declines in the ocean. Ecol Lett 13:1055-1071

Fitzpatrick SM, Keegan WF (2007) Human impacts and adaptations in the Caribbean Islands: an historical ecology approach. Earth Environ Sci Trans R Soc Edinb 98:29-45

Fokkema W, van der Jeugd HP, Lameris TK, Dokter AM and others (2020) Ontogenetic niche shifts as a driver of seasonal migration. Oecologia 193:285-297

Fox J, Weisberg S (2019) An R companion to applied regression, 3rd edn. Sage, Thousand Oaks, CA

* García VB, Lucifora LO, Myers RA (2008) The importance of habitat and life history to extinction risk in sharks, skates, rays and chimaeras. Proc R Soc B 275:83-89

*Gardner TA, Côté IM, Gill JA, Grant A, Watkinson AR (2003) Long-term region-wide declines in Caribbean corals. Science 301:958-960

Garla RC, Chapman DD, Wetherbee BM, Shivji M (2006) Movement patterns of young Caribbean reef sharks, Carcharhinus perezi, at Fernando de Noronha Archipelago, Brazil: the potential of marine protected areas for conservation of a nursery ground. Mar Biol 149:189-199

Garla RC, Gadig OBF, Garrone-Neto D (2017) Movement and activity patterns of the nurse shark, Ginglymostoma cirratum, in an oceanic Marine Protected Area of the Southwestern Atlantic. J Mar Biol Assoc UK 97:1565-1572

* Goetze JS, Langlois TJ, McCarter J, Simpfendorfer CA, Hughes A, Leve JT, Jupiter SD (2018) Drivers of reef shark abundance and biomass in the Solomon Islands. PLOS ONE 13:e0200960

Haas AR, Fedler T, Brooks EJ (2017) The contemporary economic value of elasmobranchs in The Bahamas: reaping the rewards of 25 years of stewardship and conservation. Biol Conserv 207:55-63

Harvey E, Shortis M (1995) A system for stereo-video measurement of sub-tidal organisms. Mar Technol Soc J 29: $10-22$

Heithaus MR (2001) The biology of tiger sharks, Galeocerdo cuvier, in Shark Bay, Western Australia: sex ratio, size distribution, diet, and seasonal changes in catch rates. Environ Biol Fishes 61:25-36

Heithaus M, Dill L, Marshall G, Buhleier B (2002) Habitat use and foraging behavior of tiger sharks (Galeocerdo cuvier) in a seagrass ecosystem. Mar Biol 140:237-248
Heithaus MR, Frid A, Wirsing AJ, Worm B (2008) Predicting ecological consequences of marine top predator declines. Trends Ecol Evol 23:202-210

*Heupel M, Williams A, Welch D, Ballagh A and others (2009) Effects of fishing on tropical reef associated shark populations on the Great Barrier Reef. Fish Res 95: 350-361

* Heupel MR, Papastamatiou YP, Espinoza M, Green ME, Simpfendorfer CA (2019) Reef shark science - key questions and future directions. Front Mar Sci 6:12

Hoetjes PC, Carpenter KE (2010) Saving Saba Bank: policy implications of biodiversity studies. PLOS ONE 5:e10769

*Hughes TP (1994) Catastrophes, phase shifts, and largescale degradation of a Caribbean coral reef. Science 265: 1547-1551

Jackson JB (1997) Reefs since Columbus. Coral Reefs 16(Suppl 1):S23-S32

Jackson JB, Kirby MX, Berger WH, Bjorndal KA and others (2001) Historical overfishing and the recent collapse of coastal ecosystems. Science 293:629-637

Knip DM, Heupel MR, Simpfendorfer CA (2010) Sharks in nearshore environments: models, importance, and consequences. Mar Ecol Prog Ser 402:1-11

Knip DM, Heupel MR, Simpfendorfer CA, Tobin AJ, Moloney $\mathrm{J}$ (2011) Ontogenetic shifts in movement and habitat use of juvenile pigeye sharks Carcharhinus amboinensis in a tropical nearshore region. Mar Ecol Prog Ser 425:233-246

Kyne PM, Carlson JK, Ebert DA, Fordham SV and others (2012) The conservation status of North American, Central American, and Caribbean chondrichthyans. IUCN Species Survival Commission Shark Specialist Group, Vancouver, BC

Lowe CG, Wetherbee BM, Crow GL, Tester AL (1996) Ontogenetic dietary shifts and feeding behavior of the tiger shark, Galeocerdo cuvier, in Hawaiian waters. Environ Biol Fishes 47:203-211

*MacNeil MA, Chapman DD, Heupel M, Simpfendorfer CA and others (2020) Global status and conservation potential of reef sharks. Nature 583:801-806

*McCook LJ, Ayling T, Cappo M, Choat JH and others (2010) Adaptive management of the Great Barrier Reef: a globally significant demonstration of the benefits of networks of marine reserves. Proc Natl Acad Sci USA 107: 18278-18285

Morgan A, Cooper PW, Curtis T, Burgess GH (2009) Overview of the US east coast bottom longline shark fishery, 1994-2003. Mar Fish Rev 71:23-38

* Myers RA, Baum JK, Shepherd TD, Powers SP, Peterson CH (2007) Cascading effects of the loss of apex predatory sharks from a coastal ocean. Science 315:1846-1850

Nagelkerken I, Sheaves M, Baker R, Connolly RM (2015) The seascape nursery: a novel spatial approach to identify and manage nurseries for coastal marine fauna. Fish Fish 16:362-371

Ormond R, Gore M, Bladon A, Dubock O, Kohler J, Millar C (2016) Protecting Cayman Island sharks: monitoring, movement and motive. Proc Annu Gulf Caribb Fish Inst 69:14-27

Fsgood G, Baum J (2015) Reef sharks: recent advances in ecological understanding to inform conservation. J Fish Biol 87:1489-1523

* Papastamatiou YP, Lowe CG, Caselle JE, Friedlander A (2009) Scale-dependent effects of habitat on movements and path structure of reef sharks at a predator-dominated atoll. Ecology 90:996-1008 
Pikitch EK, Chapman DD, Babcock EA, Shivji MS (2005) Habitat use and demographic population structure of elasmobranchs at a Caribbean atoll (Glover's Reef, Belize). Mar Ecol Prog Ser 302:187-197

Pratt HL, Pratt TC, Morley D, Lowerre-Barbieri S and others (2018) Partial migration of the nurse shark, Ginglymostoma cirratum (Bonnaterre), from the Dry Tortugas Islands. Environ Biol Fishes 101:515-530

R Core Team (2018) R: a language and environment for statistical computing. The $\mathrm{R}$ Foundation, Vienna. www.r-project.org

Ripley B, Venables B, Bates DM, Hornik K, Gebhardt A, Firth D, Ripley MB (2013) R package 'mass'. Cran Repository 538. https://cran.r-project.org/package=MASS

Schlegel B (2019) glm.predict: predicted values and discrete changes for GLM. R package version 3.1-0. https://cran. r-project.org/package $=$ glm.predict

Schobernd ZH, Bacheler NM, Conn PB (2014) Examining the utility of alternative video monitoring metrics for indexing reef fish abundance. Can J Fish Aquat Sci 71:464-471

Sherman CS, Chin A, Heupel MR, Simpfendorfer CA (2018) Are we underestimating elasmobranch abundances on baited remote underwater video systems (BRUVS) using traditional metrics? J Exp Mar Biol Ecol 503:80-85

Shipley ON, Howey LA, Tolentino ER, Jordan LK, Ruppert JL, Brooks EJ (2017) Horizontal and vertical movements of Caribbean reef sharks (Carcharhinus perezi): conservation implications of limited migration in a marine sanctuary. R Soc Open Sci 4:160611

Shipley ON, Brownscombe JW, Danylchuk AJ, Cooke SJ, O'Shea OR, Brooks EJ (2018) Fine-scale movement and activity patterns of Caribbean reef sharks (Carcharhinus perezi) in the Bahamas. Environ Biol Fishes 101: 1097-1104

Simpfendorfer CA, Goodreid AB, McAuley RB (2001) Size, sex and geographic variation in the diet of the tiger shark, Galeocerdo cuvier, from Western Australian waters. Environ Biol Fishes 61:37-46

Smith KN, Herrkind WF (1992) Predation on early juvenile spiny lobsters Panulirus argus (Latreille): influence of size and shelter. J Exp Mar Biol Ecol 157:3-18

Snover ML (2008) Ontogenetic habitat shifts in marine organisms: influencing factors and the impact of climate variability. Bull Mar Sci 83:53-67

Editorial responsibility: Myron Peck, Den Burg, The Netherlands

Reviewed by: 3 anonymous referees
Speed CW, Cappo M, Meekan MG (2018) Evidence for rapid recovery of shark populations within a coral reef marine protected area. Biol Conserv 220:308-319

* Stallings CD (2009) Fishery-independent data reveal negative effect of human population density on Caribbean predatory fish communities. PLOS ONE 4:e5333

* Stevens J, Bonfil R, Dulvy N, Walker P (2000) The effects of fishing on sharks, rays, and chimaeras (chondrichthyans), and the implications for marine ecosystems. ICES J Mar Sci 57:476-494

Tavares R (2009) Fishery biology of the Caribbean reef sharks, Carcharhinus perezi (Poey, 1876), in a Caribbean insular platform: Los Roques Archipelago National Park, Venezuela. Pan-Am J Aquat Sci 4:500-512

Toller W, Lundvall S (2008) Assessment of the commercial fishery of Saba Bank. Report for the Department of Environment of the Netherlands Antilles. https://www.dcbd.nl/ sites/default/files/documents/SabaBankFisheriesReportfinal_LR.pdf

* Toller W, Debrot AO, Vermeij MJ, Hoetjes PC (2010) Reef fishes of Saba Bank, Netherlands Antilles: assemblage structure across a gradient of habitat types. PLOS ONE 5:e9207

*Van Beek I, Debrot AO, Walker P, Kingma I (2014) Shark protection plan for the Dutch Caribbean EEZ (Ser. Report/ Imares Wageningen, c209/13). IMARES, Wageningen. http://edepot.wur.nl/295194

*Ward-Paige CA, Mora C, Lotze HK, Pattengill-Semmens C, McClenachan L, Arias-Castro E, Myers RA (2010) Large-scale absence of sharks on reefs in the greaterCaribbean: a footprint of human pressures. PLOS ONE 5:e11968

* Watson DL, Harvey ES, Anderson MJ, Kendrick GA (2005) A comparison of temperate reef fish assemblages recorded by three underwater stereo-video techniques. Mar Biol 148:415-425

*Werry JM, Lee SY, Otway NM, Hu Y, Sumpton W (2011) A multi-faceted approach for quantifying the estuarinenearshore transition in the life cycle of the bull shark, Carcharhinus leucas. Mar Freshw Res 62:1421-1431

*White J, Simpfendorfer CA, Tobin AJ, Heupel MR (2013) Application of baited remote underwater video surveys to quantify spatial distribution of elasmobranchs at an ecosystem scale. J Exp Mar Biol Ecol 448:281-288

Submitted: August 21, 2020

Accepted: March 5, 2021

Proofs received from author(s): April 22, 2021 